\title{
Bio-intensive integrated control of tungro disease in the rice field
}

\author{
Nur Rosida*, Ani Mugiasih, and Ahmad Muliadi \\ Indonesian Tungro Disease Research Station. Jl.Bulo No.101 Lanrang, South Sulawesi, Indonesia
}

\begin{abstract}
This research aims to gain the technology of bio-intensive integrated control of tungro. The experiments were done in a split-plot design with three replications. The main plot consisted of Bio-intensive integrated control, compared to Conventional control. The subplots are: 1) the susceptible varieties (TN1), 2) green leafhopper-resistant varieties (IR64), and 3) tungro resistant varieties (Inpari 9 Elo). The subplots are 10 $\mathrm{m} \times 10 \mathrm{~m}$, and every subplot is replicated three times. Variables observed were the population density of green leafhopper (GLH) and the predators, the percentage of tungro incidence, and the grain yield. The results showed that the population of GLH in the plots of bio-intensive integrated control $(27.32,2.34,4.83$, and 5.16) was lower than the population of GLH in conventional control $(34.00,21.17,7.84$, and 6.50). The GLH population density tends to be higher in varieties TN1 than the other varieties both in bio-intensive and conventional control. It is found that 12 species of predator exist in all varieties of bio-intensive control and conventional plots. At 8 WAT the infection of RTV on all varieties in bio-intensive plot control is lower $(0.67-2.67 \%)$ than the incidence of tungro in conventional plot control $(3.00-8.67 \%)$.
\end{abstract}

\section{Introduction}

Tungro disease is one of the main constraints in rice production (Oryza sativa L.) in Indonesia and throughout South and Southeast Asia. The threat of tungro disease in Indonesia always exists every year, which has been identified in 34 provinces [1]. The average area of tungro disease in the period 2012-2017 is 6,275 ha per year. In 2019, the area of rice crop damage nationally due to tungro attacks was 2,135 ha out of 7.46 million ha of paddy fields which were dominated by several endemic areas including West Sumatra, West Java, Bali, NTB, South Kalimantan, and Papua [1,2,3]. In South Sulawesi, tungro incidences of the past 10 years are relatively low. The lack of rice RTD inoculum sources, lower GLH population and the widespread use of resistant cultivars against RTV were the main reasons why tungro incidence decreases from time to time in South Sulawesi, although the recommendations for the appropriate planting time and cultivar rotation are no longer practiced by the farmers [4].

Tungro disease is caused by two different viruses morphologically and genetically, namely rice tungro bacilliform virus and rice tungro spherical virus [5]. Both viruses can be transmitted by several species of green leafhopper (Nephotettix spp) in semipersisten [6,7].

* Corresponding author: ochilolittungro@gmail.com 
Green leafhopper, Nephotettix virescens Distant is a member of Family Cicadellidae, Ordo Hemiptra that lives and thrives in the rice which has an important role as a virus vector of tungro. If the green leafhopper does not exist, the tungro attack likely does not occur. The spread of green leafhopper has reached Japan, India, Sri Lanka, China Malaysia, Vietnam, North Africa, South Africa and Indonesia [8]. The green leafhopper (N.virencens) ability in transmitting the virus Tungro reached $81 \%[9,10]$. The research of Rahim and Nasrudin [9] shows the effectiveness of green leafhoppers transmited the tungro virus from sources of inoculum at different incubation ages successfully contracted by $96 \%$. Tungro disease progression in rice plants has two stages. The first stage occurs due to infection in the nursery transmitted by the green leafhopper migrants, which carry the virus. The second stage occurs from the affected plants in the first stage. However, Tungro explosion occurs through a long process, i.e. the interaction between the quantity and quality of the inoculum source, transmitting insect population levels, and other supporting factors [11].

Control efforts have been carried out, but the use of pesticides is still a mainstay of farmers. On the other side, the people's demands for high quality crop, economical, and safe products for consumption are getting higher. The experience shows that the misuse of pesticides has caused many negative impacts both in resistance to the disease vector itself and to the environment. The use of pesticides in vector control will not be effective and threaten human health [12]. To improve the competitiveness and added value of rice in the market, an environmentally friendly management system of rice is needed, for example control by combining the use of resistant varieties and the conservation of natural enemies (biological agents) through the technology of bio-intensive (ecological engineering) which are economically profitable and ecologically sustainable. The objective is gaining biointensive integrated control of Tungro (proper planting time, resistant varieties, conservation of natural enemies by planting patterns of intercropping with refugia plant and rice in pressing the green leafhopper population density and the incidence of tungro disease.

\section{Materials and methods}

The research was conducted at the KP Lolittungro Lanrang, Sidrap South Sulawesi. The experiments were performed by using a split plot design in RCBD. In the main plot: 1 . We were using some environmentally friendly control components (planting time based on the recommendation, planting flowering plants (trap/puller) insects for conservation of natural enemies (predators) and using andrometa (mixture of entomopathogenic fungi Metharizium anisopliae and extract sambiloto); 2. We were preparing land and planting as usual and spraying insecticides to control green leafhopper (conventional). The subplots are: 1) the susceptible varieties (TN1), 2) common varieties in the field (IR64) and 3) tungro resistant varieties (Inpari 9 Elo). Extensive subplot $10 \mathrm{~m}$ x $10 \mathrm{~m}$ spaced $60 \mathrm{~cm}$ subplot and every subplot repeated three times.

Rice seedlings are planted at the age of 19-21 HSS. Plants are planted in a spacing of 20 $\mathrm{cm} \times 20 \mathrm{~cm}$. Plants are maintained in accordance with local farmers rice cultivation. Urea fertilizer is applied $300 \mathrm{~kg} / \mathrm{ha}$, TSP $100 \mathrm{~kg} / \mathrm{ha}$ and $\mathrm{KCl} 50 \mathrm{~kg} / \mathrm{ha}$. Urea is administered three times in $100 \mathrm{~kg}$ urea/ha as basal fertilizer, which is supplied together with $100 \mathrm{~kg} \mathrm{TSP} / \mathrm{ha}$ and $50 \mathrm{~kg} \mathrm{KCl} / \mathrm{ha}$ at planting, each $100 \mathrm{~kg}$ urea/ha when the plants reach phase maximum tillering and primordia. Weeds are cleaned manually by revoking and then buried in the ground.

Plant traps/towing insects used to conserve natural enemies are flowering plants such as: Ajeran (Bidens pilosa L.), Kenikir (Cosmos caudatus), Sunflower (Helianthus annuus L), and a Bougenville (Zinnia spp). Plant traps/towing insects were planted in the bund around the experimental plots which will be conserved. Andromeda application is a mixture of entomopathogenic fungi Metharizium anisopliae with a concentration of $2 \times 106$ conidia and sambiloto extract with a concentration of $4 \mathrm{~g} / 1$ at 2, 4, 6, and $8 \mathrm{MST}$. The content of 
secondary metabolites of sambiloto plant is lactone consisting of deoksiandrografolid, andrographolide (bitter substances) neoandrografolid, 14 - deoxy - 11-12 didehidroandrografolid and homoandrografolid. There are also flavonoids, alkane, ketone, aldehyde, minerals (potassium, roots contain flavonoid, and direct isolation polimetoksiflavon, andrografin, pan ikulin, mono-0-metilwithi and apigenin-7,4-dimetiliter. Previous research shows that compound content andrographolide in the leaves of 2.5 to $4.8 \%$ of dry weight.

Observations were made before and after the application of andromeda/biopesticide at $2,4,6$, and 8 weeks after transplanting (WAT). The variables measured were: The population density of predators, caught by using nets ten times of double swing and counting the number and type of predator. The population density of green leafhopper (GLH) caught by using nets ten times of the double swing and counting GLH. The percentage of a symptomatic clump of Tungro (\%), calculating the number of plants infected by tungro. Yields, calculating grain yield $(\mathrm{t} / \mathrm{ha})$ on a moisture content of $14 \%$. Observations were carried out a week before and after andromeda treatment. Data were analyzed by variance and if it is significantly different, then it is continued with the smallest real difference test (LSD) using SPSS 21 test.

\section{Result and discussion}

Based on observations, it was noted that both plots of bio-intensive integrated control and the conventional plots control are found in green leafhopper populations. However, when it is compared between the two treatments in this control, it noted that at 2, 4, 6, and 8 weeks after planting in the plots of bio-intensive integrated control i.e., planting time based on the recommendation, plant flowering plants as a trap/towing insects around rice plants, using andromeda (a mixture of entomopathogenic fungi Metharizium anisopliae and extract sambiloto), the population of green leafhopper (27.32, 2.34, 4.83, and 5.16) is relatively lower than the population of green leafhopper in conventional control where the farmers use pesticides $(34.00,21.17,7.84$ and 6.50).

Although green leafhoppers are not always found on all varieties in every week of observation, the green leafhopper population density generally tends to be higher in TN1 than the other varieties in both bio-intensive control and conventional control. All varieties show the growth of green leafhopper population in MST 2 even nymph population densities have reached the peak, then gradually decreased at MST 4, 6, and 8. While the adult green leafhopper population reach the peak at 4 MST and gradually decreased at MST 6 and 8. This is most likely due to adults green leafhopper are migrants from around the planting while nymphs are found as the first generation produced by the adult migrant green leafhopper in the previous week or have been carried away in the form of eggs and nymphs since from the nursery.

The emerge of adults' green leafhopper dominates until MST 4 because it is still in its formative stage population through the adjustment phase with the environmental conditions and the availability of sufficient feed. This indicates that the green leafhoppers have been successfully adapted to the cropping ecosystems conditions supported by the availability of sufficient feed to form the next generation. The population density decreases after 6 MST in plots of bio-intensive integrated control, which is caused by the higher presence of species and predator populations after being conserved with flowering plants around the perimeter bund crop and by the tendency of green leafhoppers to migrate when the crop starts its generative phase and their andromeda application. While the green leafhopper population declines in conventional plot control caused by the spraying of insecticides, that also allows the decline of green leafhopper. 
Table 1. Density of GLH population in bio-intensive integrated control of tungro dsease

\begin{tabular}{cccccccccc} 
& & \multicolumn{8}{c}{ Density of GLH population (ekor) } \\
No. & Treatment & \multicolumn{2}{c}{ 2 WAT } & \multicolumn{2}{c}{ 4 WAT } & \multicolumn{2}{c}{ 6 WAT } & \multicolumn{2}{c}{ 8 WAT } \\
\cline { 3 - 10 } & & nymph & adults & nymph & adults & nymph & adults & nymph & adults \\
\hline 1. & P1V1 & 13.33 & 3.50 & 2.67 & 5.83 & 0.00 & 0.00 & 0.00 & 1.00 \\
2. & P1V2 & 4.33 & 5.00 & 1.67 & 5.17 & 0.00 & 2.83 & 0.00 & 3.33 \\
3. & P1V3 & 0.33 & 0.83 & 1.33 & 3.67 & 0.00 & 2.00 & 0.00 & 0.83 \\
\hline & Total & \multicolumn{2}{c}{27.32} & \multicolumn{2}{c}{20.34} & 4.83 & 5.16 \\
\hline 4. & P2V1 & 2.67 & 6.00 & 2.33 & 8.17 & 0.00 & 3.00 & 3.00 & 1.83 \\
5. & P2V2 & 3.67 & 7.33 & 1.00 & 4.17 & 0.00 & 2.17 & 0.00 & 0.17 \\
6. & P2V3 & 8.33 & 6.00 & 1.00 & 4.50 & 0.00 & 2.67 & 0.00 & 1.50 \\
\hline & Total & \multicolumn{2}{c}{34.00} & \multicolumn{2}{c}{21.17} & \multicolumn{2}{c}{7.84} & \multicolumn{2}{c}{6.50} \\
\hline
\end{tabular}

P1: Bio-intensive integrated control; P2: Conventional control; V1: TN1 (susceptible varieties); V2 : IR 64 (GLH - resistant varieties); V3 : Inpari 9 (tungro resistant- varieties).

Natural enemies found in all varieties in the plots of bio-intensive integrated control and in the plots of conventional controls are 12 species i.e., Synharmonia octomaculata, Ophionea nigrofasciata, Paederus fuscipes, Conocephalus longipennis, Agriocnemis spp., Agriocnemis spp., Araneus inustus, Lycosa pseudoannulata, Oxyopes javanus, Tetragnatha maxillosa, Anaxipha longipennis, and Solepnopsis geminate but they are not found in every week of observation (Table 2, 3, 4 and 5). The number of individuals found in each week of observation, shows that the fluctuation population of each predator. Araneus inustus and Tetragnatha maxillosa dominate in plots of bio-intensive control and conventional control. In general, fluctuations in the population density of predators follows the pattern of density fluctuations of green leafhopper populations.

The existence of predatory species in all planting time indicates that predator species, the environment and the prey availability of prey are appropriate even though the appearance could not be found at all weeks of observation and varieties. According to Gurr [13], the density fluctuations are influenced by predator prey density. The higher number of prey populations, the higher number of predators are. The process of interaction of predators and prey in each variety has been started since MST 2. Andromeda treatment in the crop does not have an impact on species diversity and the density fluctuation of predator species. Andromeda treatment in each week is not positively correlated with the pattern of density fluctuations of the population in each week of observation.

The population of natural enemies found in the plots of bio-intensive and conventional control are not significantly different. This is likely due to the time of planting flowering plants that are less appropriate to the period of the presence of natural enemies. Planting is performed at least ten days before the seedbed. The expected period of flowering will exact in conjunction with the beginning of the rice planting, so that the population of natural enemies will increase along with the existence of the flower plants.

By planting flowering plants, the green leafhopper population is suspected to be lower than a population of natural enemies on the plot of bio-intensive integrated control. This is in line with the results of the application of ecological engineering in Jinhua and Lingui, China which suggested that ecological engineering can enhance natural enemy populations [13]. The population of natural enemies on ecological engineering plots is higher than the plots of farmers. In addition, the WBC population found in ecological engineering plots is lower than the plot of farmers. 
Table 2. The type and population density of predators on the plot of bio-intensive integrated control of tungro disease and conventional plots control in Sidrap

P1: bio-intensive integrated control; P2: Conventional control; V1: TN1 (susceptible varieties); V2: IR 64 (green leafhopper resistant- varieties); V3: Inpari 9 (tungro resistant-varieties)

\begin{tabular}{|c|c|c|c|c|c|c|c|c|c|c|c|c|c|}
\hline \multirow{3}{*}{ No } & \multirow{3}{*}{ treatment } & \multicolumn{12}{|c|}{ Population Predator } \\
\hline & & \multicolumn{12}{|c|}{ 2 WAT } \\
\hline & & $\begin{array}{l}\text { Synharmonia } \\
\text { octomaculata }\end{array}$ & $\begin{array}{c}\text { Ophionea } \\
\text { nigrofasciata }\end{array}$ & $\begin{array}{l}\text { Paederus } \\
\text { fuscipes }\end{array}$ & $\begin{array}{l}\text { Conocephalus } \\
\text { longipennis }\end{array}$ & $\begin{array}{l}\text { Agriocnemis } \\
\text { spp. }\end{array}$ & $\begin{array}{c}\text { Araneus } \\
\text { inustus }\end{array}$ & $\begin{array}{c}\text { Lycosa } \\
\text { pseudoannulata }\end{array}$ & $\begin{array}{c}\text { Oxyopes } \\
\text { javanus }\end{array}$ & $\begin{array}{l}\text { Phiddupas } \\
\text { sp }\end{array}$ & $\begin{array}{l}\text { Tetragnatha } \\
\text { maxillosa }\end{array}$ & $\begin{array}{l}\text { Anaxipha } \\
\text { longipennis }\end{array}$ & $\begin{array}{l}\text { Solepnopsis } \\
\text { geminate }\end{array}$ \\
\hline 1 & P1V1 & 0.00 & 0.00 & 0.00 & 0.00 & 1.00 & 20.00 & 0.00 & 0.00 & 0.00 & 48.33 & 0.00 & 0.00 \\
\hline 2 & P1V2 & 0.33 & 0.00 & 0.00 & 0.00 & 1.67 & 60.00 & 0.00 & 1.33 & 0.00 & 52.67 & 0.00 & 0.00 \\
\hline 3 & P1V3 & 1.00 & 0.00 & 0.00 & 0.00 & 2.33 & 12.67 & 0.00 & 0.00 & 0.00 & 15.67 & 0.00 & 0.00 \\
\hline 4 & $\mathrm{P} 2 \mathrm{~V} 1$ & 0.33 & 0.00 & 0.00 & 0.00 & 0.67 & 18.00 & 0.00 & 0.00 & 0.00 & 12.33 & 0.00 & 0.00 \\
\hline 5 & $\mathrm{P} 2 \mathrm{~V} 2$ & 1.00 & 0.00 & 0.00 & 0.00 & 0.00 & 43.67 & 1.00 & 0.33 & 0.00 & 41.00 & 0.00 & 0.00 \\
\hline 6 & P2V3 & 0.67 & 0.00 & 0.00 & 1.00 & 0.67 & 34.00 & 0.00 & 0.00 & 0.00 & 33.00 & 0.00 & 0.00 \\
\hline
\end{tabular}

Table 3. The type and population density of predators on the plot of bio-intensive integrated control of tungro disease and conventional plots control in Sidrap P1: bio-intensive integrated control; P2 : Conventional control; V1 : TN1 (susceptible varieties); V2 : IR 64 (green leafhopper resistant- varieties); V3 : Inpari 9 (tungro reistant-varieties)

\begin{tabular}{|c|c|c|c|c|c|c|c|c|c|c|c|c|c|}
\hline \multirow{3}{*}{ No } & \multirow{3}{*}{ Treatment } & \multicolumn{12}{|c|}{ Population of Predator (ekor) } \\
\hline & & \multicolumn{12}{|c|}{4 WAT } \\
\hline & & $\begin{array}{l}\text { Synharmonia } \\
\text { octomaculata }\end{array}$ & $\begin{array}{l}\text { Ophionea } \\
\text { nigrofasciata }\end{array}$ & $\begin{array}{l}\text { Paederus } \\
\text { fuscipes }\end{array}$ & $\begin{array}{l}\text { Conocephalus } \\
\text { longipennis }\end{array}$ & $\begin{array}{l}\text { Agriocne } \\
\text { mis spp. }\end{array}$ & $\begin{array}{l}\text { Araneus } \\
\text { inustus }\end{array}$ & $\begin{array}{l}\text { Lycosa pseudo } \\
\text { annulata }\end{array}$ & $\begin{array}{l}\text { Oxyopes } \\
\text { javanus }\end{array}$ & $\begin{array}{l}\text { Phiddupas } \\
\text { sp }\end{array}$ & $\begin{array}{l}\text { Tetragnatha } \\
\text { maxillosa }\end{array}$ & $\begin{array}{l}\text { Anaxipha } \\
\text { longipennis }\end{array}$ & $\begin{array}{l}\text { Solepnopsi } \\
s \text { eminate }\end{array}$ \\
\hline 1 & P1V1 & 0.67 & 0.00 & 0.00 & 17.00 & 5.33 & 33.33 & 0.00 & 1.33 & 0.00 & 16.67 & 0.00 & 0.00 \\
\hline 2 & P1V2 & 4.67 & 0.00 & 0.00 & 15.67 & 13.00 & 18.00 & 0.00 & 6.67 & 0.00 & 10.33 & 0.00 & 0.00 \\
\hline 3 & PIV3 & 1.00 & 0.00 & 0.00 & 0.00 & 10.00 & 21.00 & 0.00 & 6.00 & 0.00 & 28.67 & 0.00 & 0.00 \\
\hline 4 & $\mathrm{P} 2 \mathrm{~V} 1$ & 4.67 & 0.00 & 0.00 & 0.00 & 6.00 & 27.33 & 0.00 & 4.67 & 0.00 & 17.00 & 0.33 & 0.00 \\
\hline 5 & $\mathrm{P} 2 \mathrm{~V} 2$ & 3.33 & 0.00 & 0.00 & 0.00 & 8.00 & 30.00 & 0.00 & 0.00 & 0.00 & 24.67 & 0.00 & 0.00 \\
\hline 6 & P2V3 & 0.67 & 0.00 & 0.00 & 0.00 & 6.67 & 24.33 & 0.00 & 4.67 & 0.00 & 6.33 & 0.00 & 0.00 \\
\hline
\end{tabular}


Table 4. The type and population density of predators on the plot of bio - intensive integrated control of tungro disease and conventional plots control in Sidrap, South Sulawesi

P1: bio-intensive integrated control; P2: Conventional control; V1: TN1 (susceptible varieties); V2: IR 64 (green leafhopper resistant- varieties); V3 : Inpari 9 tungro reistant-varieties).

\begin{tabular}{|c|c|c|c|c|c|c|c|c|c|c|c|c|c|}
\hline \multirow[b]{3}{*}{ No } & \multirow[b]{3}{*}{ Treatment } & \multicolumn{12}{|c|}{ Population of Predator (ekor) } \\
\hline & & \multicolumn{12}{|c|}{$6 \mathrm{WAT}$} \\
\hline & & $\begin{array}{l}\text { Synharmonia } \\
\text { octomaculata }\end{array}$ & $\begin{array}{l}\text { Ophionea } \\
\text { nigrofasciata }\end{array}$ & $\begin{array}{l}\text { Paederus } \\
\text { fuscipes }\end{array}$ & $\begin{array}{l}\text { Conocephalus } \\
\text { longipennis }\end{array}$ & $\begin{array}{l}\text { Agriocne } \\
\text { mis spp. }\end{array}$ & $\begin{array}{l}\text { Araneus } \\
\text { inustus }\end{array}$ & $\begin{array}{l}\text { Lycosa } \\
\text { pseudoannulata }\end{array}$ & $\begin{array}{l}\text { Oxyopes } \\
\text { javanus }\end{array}$ & $\begin{array}{l}\text { Phiddu } \\
\text { pas sp }\end{array}$ & $\begin{array}{l}\text { Tetragnath } \\
\text { a maxillosa }\end{array}$ & $\begin{array}{l}\text { Anaxipha } \\
\text { longipennis }\end{array}$ & $\begin{array}{l}\text { Solepnops } \\
\text { is } \\
\text { eminate }\end{array}$ \\
\hline 1 & P1V1 & 0.00 & 0.33 & 0.00 & 0.00 & 0.33 & 5.00 & 0.00 & 0.33 & 0.00 & 0.33 & 0.33 & 0.00 \\
\hline 2 & P1V2 & 0.33 & 1.00 & 0.00 & 0.33 & 0.00 & 4.67 & 0.67 & 0.33 & 0.00 & 1.33 & 0.00 & 0.00 \\
\hline 3 & P1V3 & 0.67 & 0.00 & 0.33 & 0.00 & 0.33 & 1.33 & 0.33 & 0.33 & 0.00 & 1.33 & 0.67 & 0.00 \\
\hline 4 & $\mathrm{P} 2 \mathrm{~V} 1$ & 0.33 & 0.67 & 0.00 & 0.00 & 1.33 & 6.00 & 0.00 & 0.67 & 0.00 & 1.33 & 0.67 & 0.00 \\
\hline 5 & $\mathrm{P} 2 \mathrm{~V} 2$ & 0.00 & 1.00 & 0.00 & 0.33 & 0.00 & 4.33 & 0.00 & 0.00 & 0.00 & 1.67 & 0.33 & 0.00 \\
\hline 6 & $\mathrm{P} 2 \mathrm{~V} 3$ & 0.00 & 0.33 & 0.00 & 0.00 & 0.67 & 2.00 & 0.00 & 1.00 & 0.67 & 1.33 & 0.00 & 0.00 \\
\hline
\end{tabular}

Table 5. The type and population density of predators on the plot of bio - intensive integrated control of tungro disease and conventional plots control in KP Lanrang

P1: bio-intensive integrated control; P2: Conventional control; V1: TN1 (susceptible varieties); V2: IR 64 (green leafhopper resistant- varieties); V3:

\begin{tabular}{|c|c|c|c|c|c|c|c|c|c|c|c|c|c|}
\hline \multirow{3}{*}{ No } & \multirow{3}{*}{ Treatment } & \multicolumn{12}{|c|}{ Population of Predator (ekor) } \\
\hline & & \multicolumn{12}{|c|}{ 8 WAT } \\
\hline & & $\begin{array}{l}\text { Synharmonia } \\
\text { octomaculata }\end{array}$ & $\begin{array}{l}\text { Ophionea } \\
\text { nigrofasciata }\end{array}$ & $\begin{array}{l}\text { Paederus } \\
\text { fuscipes }\end{array}$ & $\begin{array}{l}\text { Conocephalus } \\
\text { longipennis }\end{array}$ & $\begin{array}{l}\text { Agrioc } \\
\text { nemis spp. }\end{array}$ & $\begin{array}{l}\text { Araneus } \\
\text { inustus }\end{array}$ & $\begin{array}{l}\text { Lycosa } \\
\text { pseudoannulata }\end{array}$ & $\begin{array}{l}\text { Oxyopes } \\
\text { javanus }\end{array}$ & $\begin{array}{l}\text { Phid } \\
\text { dupas sp }\end{array}$ & $\begin{array}{l}\text { Tetragnatha } \\
\text { maxillosa }\end{array}$ & $\begin{array}{l}\text { Anaxipha } \\
\text { longipennis }\end{array}$ & $\begin{array}{l}\text { Solepnopsis } \\
\text { eminate }\end{array}$ \\
\hline 1 & P1V1 & 2.00 & 0.33 & 0.33 & 0.00 & 0.00 & 0.67 & 0.33 & 0.00 & 0.00 & 2.33 & 0.00 & 0.00 \\
\hline 2 & P1V2 & 8.00 & 0.00 & 0.00 & 1.33 & 2.00 & 4.33 & 0.00 & 1.33 & 0.00 & 4.67 & 0.33 & 0.00 \\
\hline 3 & P1V3 & 4.00 & 0.00 & 0.00 & 0.00 & 0.00 & 2.67 & 0.00 & 0.33 & 0.00 & 0.00 & 0.00 & 0.00 \\
\hline 4 & $\mathrm{P} 2 \mathrm{~V} 1$ & 2.00 & 0.67 & 0.00 & 0.00 & 4.00 & 2.67 & 0.33 & 0.00 & 0.00 & 1.67 & 0.00 & 0.00 \\
\hline 5 & P2V2 & 1.00 & 0.33 & 0.00 & 0.00 & 1.67 & 4.67 & 0.33 & 0.00 & 0.00 & 4.33 & 0.33 & 0.00 \\
\hline 6 & P2V3 & 1.00 & 0.00 & 0.00 & 0.00 & 1.67 & 4.33 & 0.67 & 1.67 & 0.00 & 2.33 & 0.00 & 0.00 \\
\hline
\end{tabular}


The symptoms of Tungro is not found at MST 2 and 4. The tungro symptoms began to appear on the MST 6 and 8 both in bio-intensive integrated control and in conventional control plots. The percentage of Tungro attacks at MST 8 on all varieties in bio-intensive control plots is lower $(0.67-2.67 \%)$ than the percentage of Tungro attacks in the conventional control plot $(3.00$ $8.67 \%$ ). This is caused by the green leafhopper population density in the plots of bio-intensive integrated control is higher than in a conventional control plot. Tungro incident that occurred is inherited from the green leafhopper found in the beginning vegetative plantation ( 2 and 4 WAT) with higher population density. In the following weeks 6 and 8 WAT) reach the peak of Tungro infection because it provided a source of inoculum and green leafhopper populations in the crop, which lead to high percentage of Tungro attacks. In addition, the increasing of tungro incidence indicates the secondary transmission by green leafhoppers from previously infected plants.

In general, the andromeda applications do not directly affect the existence of type and population density of predators. Likewise, on the pattern of density fluctuations of green leafhopper populations that follow the pattern seen in the trial area. During the observation, there is no green leafhopper dying caused by M. anisopliae fungi. Andromeda treatment is supposed to give influence to the inhibition in the process of viral infection of the disease. Technical, cultural activities through trimming weeds in the bund at 2 and 4 WAT are suspected to contributing to the elimination of secondary inoculum source and improve the process of predation against green leafhoppers during critical phases of Tungro infection, so Tungro incidence that occurred is relatively low.

Table 6. Incidence of Tungro in plots of bio-intensive integrated control of tungro disease and conventional plots control in Sidrap, South Sulawesi.

\begin{tabular}{cccccc}
\hline \multirow{2}{*}{ No } & \multirow{2}{*}{ Treatment } & \multicolumn{4}{c}{ Percentage of incidence of Tungro (\%) } \\
\cline { 2 - 5 } & & MST 2 & MST 4 & MST 6 & MST 8 \\
\hline 1 & P1V1 & 0.00 & 0.00 & 3.67 & 0.67 \\
2 & P1V2 & 0.00 & 0.00 & 2.00 & 1.00 \\
3 & P1V3 & 0.00 & 0.00 & 2.67 & 2.67 \\
4 & P2V1 & 0.00 & 0.00 & 0.33 & 8.67 \\
5 & P2V2 & 0.00 & 0.00 & 0.67 & 3.67 \\
6 & P2V3 & 0.00 & 0.00 & 1.33 & 3.00 \\
\hline
\end{tabular}

P1 : bio-intensive integrated control; P2 : Conventional control; V1 : TN1 susceptible varieties); V2 : IR 64 (green leafhopper resistant- varieties); V3 : Inpari 9 (tungro resistant-varieties).

Yields showed that grain weight on a plot of bio-intensive integrated control tungro disease in all varieties (2.17- 3.65 t/ha) was not significantly different from controls grain weight on the conventional plots (3.29-3.65 t/ha). Andromeda applications does not affect the crops due to varieties applied with andrometa (plots of bio-intensive integrated control) and did not apply (conventional plot control).

Table 7. Yields on plots of bio-intensive integrated control of tungro disease and conventional plots control in Sidrap, South Sulawesi

\begin{tabular}{ccc}
\hline No & Treatment & Yields (t/ha) \\
\hline 1 & P1V1 & 3.29 \\
2 & P1V2 & 3.69 \\
3 & P1V3 & 3.29 \\
\hline 4 & P2V1 & 3.06 \\
5 & P2V2 & 3.65 \\
6 & P2V3 & 2.17 \\
\hline
\end{tabular}

P1 : bio-intensive integrated control; P2 : Conventional control; V1 : TN1 (susceptible varieties); V2 : IR 64 (green leafhopper resistant- varieties); V3 : Inpari 9 (tungro resistant-varieties). 


\section{Conclusion}

The study results suggested that the population of GLH in the plots of bio-intensive integrated control lower than the population of GLH in conventional control. The green leafhopper population density tends to be higher in varieties TN1 than the other varieties both in biointensive and conventional control. It is found that 12 species of predator exist, i.e. Synharmonia octomaculata, Ophionea nigrofasciata, Paederus fuscipes, Conocephalus longipennis, Agriocnemis spp., Araneus inustus, Lycosa pseudoannulata, Oxyopes javanus, Phiddupas sp., Tetragnatha maxillosa, Anaxipha longipennis, dan Solepnopsis geminatein all varieties of biointensive control and conventional plots. The infection of RTV on all varieties in bio-intensive plot control is lower $(0.67-2.67 \%)$ than the incidence of tungro in conventional plot control $3.00-8.67 \%)$.

It is recommended that planting of flowering plants on bunds is performed prior to the nursery and controlling the growth of the plant in order to make the ecological engineering increase the biodiversity of natural enemies. It is also recommended that the application of biointensive control is continued in a wider agriculture area (min-1 ha) in order to support environmentally friendly and sustainable agricultural system.

\section{References}

1. PUSDATIN (Pusat Data dan Sistem Informasi Pertanian). Statistics of Climate, Crop Pest and Climate Change Impact 2014-2017 (Accessed 16 Januari 2018).

2. BBPOPT. Prakiraan Serangan Tungro di Indonesia MT 2019-2020. https://bbpopt.id/ index.php/2020/04/09/prakiraan-serangan-tungro-di-indonesia-mt-2019-2020/ (Accessed 28 April 2020).

3. DITLIN (Direktorat Perlindungan Tanaman Pangan). 2019. Laporan Serangan OPT dan DPI Direktorat Perlindungan Tanaman Pangan Periode 11 Oktober 2019 (Luas Serangan Organisme Penganggu Tumbuhan (OPT) Utama pada Tanaman Padi). http://ditlin.tanamanpangan.pertanian.go.id/index.php/artikel/opt_dan_dpi (Accessed 20 December 2019).

4. N. Rosida, T. Kuswinanti, N. Amin, A. Nasruddin. J. Biol. Sci. 20, 4, (2020)

5. Bunawan, Hamidun, L. Dusik, S.N. Bunawan, M.M. Amin. World Applied Sci. J. 31, 6, (2014)

6. H. Hibino. Japanese J. Phytopathology, 49, 4, (1983)

7. S.S. Siwi, A. Kartohardjono, S. Harnoto, A. Diratmaja. The green leafhopper, genus nephotettix matsumura. Proc. of the Workshop on Rice Tungro Virus, Maros, (1986)

8. Supriadi, K. Untung, A. Trisyono, T. Yuwono. Keragaman populasi wereng hijau, nephotettix virescens distant (Hemiptra:Cicadellidae) asal wilayah endemis dan non endemis penyakit tungro padi. Seminar Nasional V Perhimpunan Entomologi (PEI), Bogor, (2008)

9. M.D. Rahim, A. Nasruddin. J. Fitomedika, 7, 1, (2010)

10. S.F. Savary, S.F. Horgan, L. Willocquet, K.L. Heong. Crop Protection, 32,_(2012)

11. H. Hibino. Annual Review of Phytopathology, 34, 1, (1996)

12. BBPOPT. Prakiraan Serangan OPT Utama Padi, Jagung dan Kedelai MT.2019-2020. Balai Besar Peramalan Organisme Pengganggu Tumbuhan. Direktorat Jenderal Tanaman Pangan. Kementerian Pertanian http://sipetani.pertanian.go.id:8081/siperditan/ rekomenpdf/opttp/. 2019.

13. G.M. Gurr. Ecological engineering to reduce rice crop vulnerability to planthopper outbreaks. (Charles Sturt University. Australia, 2010) 